\title{
Herbert Luther Bodman
}

1924-2011

Herbert luther Bodman, Jr., died in Chapel Hill on February 6, 2011, at the age of 86. He was a key figure in the development of Middle Eastern studies at the University of North Carolina at Chapel Hill, having introduced Islamic civilization to the university's history curriculum in 1958.

Born in 1924 in New York City, Herb Bodman departed from the traditional family occupation in New York banking to venture south to study history at UNC (B.A. 1947) and Princeton University (Ph.D. 1955), with a dissertation later published as Political Factions in Aleppo, 1760-1826 (University of North Carolina Press, 1962). He taught at the American University in Beirut and McGill University, and worked for the U.S. Information Agency on the Middle East Desk in Washington, D.C. He was then recruited as professor of Middle East history at Carolina, a job he enjoyed until his retirement in 1989. His many students include Professor William A. Graham and Ambassador Karl Inderfurth.

Herb and his wife Ellen-Fairbanks D. Bodman (affectionately known as Taffy) worked extensively over the years with the Middle East Studies Association (MESA), particularly in hosting the MESA annual conference in North Carolina in 1993. He was also a strong supporter of the Southeast Regional Middle East and Islamic Studies Seminar (SERMEISS), mentoring high school teachers and encouraging others in the study of Islamic societies. He was the principal director of the American Council of Learned Societies-funded Islamic Teaching Materials Project, which included a collection of translated primary sources in microform, consisting of a bibliography, filmography, maps, books, and other teaching resources for high school and college courses. This collection was edited by William A. Graham, Marilyn Robinson Waldman, and Miryam Rozen, and published as Islam-Fiche (Zug, Switzerland: Inter Documentation Co., 1983). The same project included a collection of color slides entitled The Lands and People of Islam: A Traditional Perspective, which Herb co-edited with R. Stephen Humphreys (ACLS, 1987). He also was a contributor to a popular anthology of humanistic texts, The Humanities: Cultural Roots and Continuities, edited by 
Mary Ann Frese Witt (4th ed., Lexington, Mass.: D.C. Heath, 1993).His Women in the Muslim World: A Bibliography of Books and Articles Primarily in the English Language was published by MESA in 1991. He co-edited Women in Islamic Societies with Nayereh Tohidi (Lynne Rienner Publishers, 1998) and wrote numerous book and film reviews.

Herb Bodman will be particularly remembered for his role in the development of Middle Eastern and Islamic studies at UNC and allied institutions, having established an enduring collaboration between UNC and Duke University through jointly taught courses, a tradition that continues today. \&

Carl W. Ernst

University of North Carolina at Chapel Hill

\section{Ernst J. Grube}

\section{2-2011}

ERnSt J. Grube WAS BORn ON 9 MAy 1932 in Austria but was raised and educated in Berlin, attending the Schiller-Gymnasium and then the Free University from which he obtained his doctorate in 1955. In the same year he went to work in the Art Library of the Berlin State Museums as an assistant, but soon moved to the Islamic Department at the invitation of Ernst Kuhnel, where he worked until 1958. In that year he was offered a research grant at The Metropolitan Museum of Art in New York and in 1959 he joined the Met's Department of Near Eastern Art. What is not widely known is that in 1962 Ernst was appointed Curator of the newly established Department of Islamic Art and, and to the best of my knowledge, was the first scholar to hold such a named position anywhere in the world.

At the same time Ernst taught Islamic Art as an Adjunct Professor at Columbia University, and after leaving the Met in 1969 he taught both Islamic and Far Eastern art history at Hunter College. He moved to Italy in 1972, where he taught Islamic art history first at the University of Padua and, from 1973, at the Oriental Institute in Naples. In 1977 he was appointed to the Chair of Islamic art history at the University of Venice, from which 